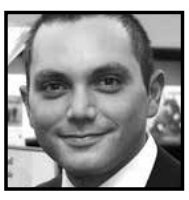

\title{
Taking Action in Teacher Education: Social Studies as a Means of Cultivating Engaged Citizenship
}

Theodore Michael Christou, Queen's University

\begin{abstract}
Social Studies was introduced into the Ontario curriculum in 1937, integrating history and geography, but also various matters pertaining to law, government, and civics, as a means of focusing students' attention on the world around them thoughtfully and critically. Informed by the past, students were directed to gaze upon the future and to take action within their communities. Civic engagement and Social Studies were very closely linked. This essay argues that Social Studies education has a particular role to play in teacher education, as a medium of cultivating meaningful experiences relating to contemporary life and as a means of exploring the disciplinary roots of the subject. Teacher education is explored as a site for "take action" projects, which relate citizenship, historical thinking, and social action.
\end{abstract}

\section{Introduction}

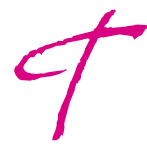

his paper explores Social Studies as a curriculum subject and as an aspect of teacher education at the elementary level. In particular, it focuses on the historical purposes of the subject in Ontario-social justice and civic engagement-and it explores Take Action projects as a means of relating contemporary teaching methods to these purposes. The paper argues that exploration of the unique history and foundations of Social Studies is imperative within the context of teacher education. Further, the paper argues that teacher candidates should have opportunities to do Social Studies rather than to learn about the subject. While the 
discussion focuses on Ontario, Social Studies methods courses are a staple across the landscape of Canadian teacher education.

Unlike most subjects that form the basis of public school curricula in Canada, Social Studies has a birth date. It is hard to trace when, for instance, English became a school subject, yet in Ontario, the subject was introduced in 1937; at the elementary level, it served as a means of integrating history and geography, but also various matters pertaining to law, government, and civics, as a means of concentrating students' attention on the world around them thoughtfully and critically (Christou, 2012). The Social Studies curriculum was fashioned in the cauldron of post-Depression era progressivist thinking about project-based learning (called enterprises) and social justice. One year earlier, Alberta was the first Canadian province to include Social Studies as a distinct subject in the formal curriculum (von Heyking, 2006).

\section{Social Studies Seen Historically}

Social Studies has a particular role to play in schooling and, more specifically, in teacher education. The subject's educative potential is firmly rooted in its history. At the time of its foundation within the Canadian curriculum context, Social Studies was meant to foster an ethos of social action in teachers and learners, whilst simultaneously facilitating an ethos of sustained civic engagement (Christou, 2013).

The year 2014 marks the 87th birthday of the Social Studies in Ontario. This reminder may serve as a prompt to teacher educators and teacher candidates, primarily those involved with the elementary grades, to reevaluate commonplace teaching and learning practices. It is vital that teacher candidates understand the particular purposes that Social Studies were meant to fulfill within Canadian schools. In practice, the subject risks being conflated with banal and superficial engagements of popular teaching units that focus on inquiry into pioneer villages or medieval times.

Engaging teacher candidates with curriculum history and with Take Action projects during the tenure of their teacher education program can serve two purposes: a) demonstrate how one involves a group of learners with the practical concerns of the broader community; and b) foster historical thinking, which is fundamental to the development of historical literacy on a metacognitive level. Both purposes are more valuable than the memorization of historical and geographical content that will soon be forgotten. This is particularly pertinent in teacher education. In this context, teacher candidates must overcome the "apprenticeship of observation" (Lortie, 1975), the formative influence that hundreds of hours spent in the classroom as students has 
had on their conceptions of teaching and learning. This overcoming is facilitated by, if not dependent upon, opportunities to experience "contexts of productive learning" (Sarason, 1996, p. 343) during the course of preservice teacher education programs. When teacher candidates have the opportunity to experience Social Studies projects that engage them meaningfully with the tasks of citizenship, they have occasions to conceptualize teaching and learning in potentially different and dynamic ways.

Shirley Engle (1986), commenting on the Social Studies, identified the tension that arises in teacher education where learners are told about their disciplines without ever engaging with them:

For reasons I have never fully understood, most history professors completely change their colors when they step out of their role as research scholars and take on the mantle of "herr" professor. As scholars, they hold truth in great tenuousness; they are not all of one mind; their disciplines are hotbeds of controversy; they are forever correcting one another's errors. But once they have laid aside their research eyeshades and donned the teaching robes, they become authorities whose mission is considered to be the transmission of their superior knowledge to students. (p. 21)

Engle makes three critical points that relate to the teaching of Social Studies within teacher education institutions. First, the subject should not be concerned simply with the transmission of knowledge; this leads to inert understanding and passive approaches to learning. Second, it is entirely appropriate, if not essential, to introduce students to authentic social problems and dilemmas, which challenge teacher candidates to work on solutions and plan appropriate action. Third, authentic scholarship in Social Studies involves controversy and uncertainty; neat parcels of knowledge are disconnected from the messy reality of social living and the transformative nature of scholarship.

When discussing the Social Studies in the province of Ontario, one exclusively considers Grades 1-6. Ontario's students begin a more disciplinary approach in Grade 7, as History and Geography replace the Social Studies. Outside of Ontario, with the exception of Quebec, the subject persists into middle school and secondary school education. With respect to teacher education, then, the discussion here relates most explicitly to that in the Primary and Junior Divisions, wherein every candidate within the Ontarian context is by necessity enrolled in a curriculum course in Social Studies methods.

These methods courses tend to concentrate on an examination of the curriculum, on lesson and unit planning, on resource development, and on some aspect of experiential learning. Regardless of context, Ken Osborne (2012) notes: 
Since at least the 1890s, historians and history educators have largely agreed that students must learn to approach the facts of history critically, not least by understanding the relationship between "the past" and "history." ... However, researchers have repeatedly shown that classroom practice often lags far behind the principles formulated by historians and history educators. (p. v)

His essay reminds us that the teaching of Social Studies is, despite a century-long debate, still predominately taught using pre-fabricated units, even as history is learned via textbooks and limited to recitation. "All too often," he laments, "history is not a stimulus to thought and imagination, but merely a charge on the memory, and usually a short-lived charge at that" (p. v).

From a curricular standpoint, Quebec stands alone in offering courses in Social Sciences at the elementary and secondary level. Social Sciences are inclusive of History, Geography, and Citizenship education and, in this respect, are similar to Social Studies as understood outside of Ontario. The objective of Quebec's elementary Social Sciences curriculum is to help the student "to construct his/her social awareness in order to act as a responsible, informed citizen" (Quebec Ministry of Education, 2001, p. 181) and it encompasses three "cycles" that are typical of the expanding horizons model of Social Studies education; this model, which is recognizable across North America, involves a progression from the study of one's self in space and time to increasingly distant contexts, both historical and geographical (Wade, 2002; BoyleBaise \& Zevin, 2013). Quebec's unique approach to history education has been studied historically (Bouvier, Allard, Aubin, \& Larouche, 2012) and contemporaneously (Létourneau, 2011; Éthier \& Lefrançois, 2011) in relation to the province's particular challenges and educational concerns.

Within the Ontarian context, the particular roots of Social Studies as a curriculum subject belie its current disconnectedness from social life. The subject's foundations are intertwined with the person of Duncan McArthur-historian, educator, and namesake of Queen's University's Faculty of Education-who served as Minister of Education in 1937. This is year that Social Studies was introduced to Ontario's formal curriculum, or Programme of Studies. His vision for education was rooted in a vision of social cooperation and active engagement with the world (Christou, 2013). What characterized the 1937 Programme was a desire to transform a course of studies seen as overly concerned with the inculcation of academic knowledge. Textbook learning, as McArthur noted in 1934, was not only narrow, but its mandate also compelled teachers to push through textbooks at the peril of ignoring broad student interest, activity, and exploration: 
The system of authorizing special text-books for courses of study has likewise led to the encouragement of the formation of habits of mind which cannot be regarded as otherwise than undesirable. The authorizing of a particular book as a text gives to the printed word within the book a literal inspiration. It becomes easy for the student to assume that all of the truth relating to a subject is contained within the covers of the book. (cited in Christou, 2013, p. 288)

McArthur believed education that focuses on memorization and recall of facts, figures, and dates does not make students historically, or socially, literate. Facts and figures, historical and otherwise, "once committed to memory are soon forgotten. The information temporarily acquired is seldom related to the structure of knowledge or experience possessed by the pupil" (p. 288).

Teacher candidates should have the opportunity to think about what Social Studies was meant to accomplish and, by implication, what it can serve to do within the broader scope of public education. The subject may be conceptualized as a means of provoking wonder and encouraging civic action within a teacher education program. In relation to civic action, Social Studies facilitates opportunities for teacher candidates to consider how they can create learning spaces for their students that will challenge them to think about their place in the world and what it means to live ethically and well.

\section{Social Studies and Social Life}

In The School and the Society, John Dewey (1907) argues that schoolwork and lessons, consequently, can be judged in "relation to human activity-so that they are not simply external facts, but are fused and welded with social conceptions regarding the life and progress of humanity" (p. 64). Dewey was troubled by the absence of a meaningful relationship between school activities and the authentic challenges of life. Engaging students with these challenges was a principle impetus in early Social Studies education (Christou, 2012), and it reserves the potential to be a powerful means of developing cultivating civic engagement and historical literacy.

The Historical Thinking Concepts developed at the Centre for Historical Consciousness at the University of British Columbia offer a conceptual and linguistic framework for working with the concept of historical literacy. Most recently, under the leadership of Peter Seixas, Canada Research Chair in Historical Thinking at the University of British Columbia, this framework has been rearticulated as The Big Six Historical Thinking Concepts. The six concepts articulation serves as a linguistic and cognitive frame for teacher education and professional development (Seixas \& Morton, 2012). 
In 2013, these concepts were cited and used as a structural framework in Ontario's revised Social Studies curriculum (Ontario Ministry of Education, 2013). Ontario was among the last provinces to adopt the framework, following jurisdictions such as Alberta, British Columbia, and New Brunswick, which spearheaded these reforms.

The reforms, which focus on the explicit engagement with historical thinking and active learning in Social Studies classrooms, are rooted in the pedagogical terrain that John Dewey (1907) tilled a century ago when he argued that teaching and learning tasks must correlate to authentic life activities. As Social Studies methods courses are effectively concentrated upon the curriculum expectations for the subject, teacher candidates must now reconfigure their thinking even as the curriculum document itself has undergone a paradigm shift in Ontario. Candidates must find a way to do Social Studies with students. They cannot no longer teach the subject out of a textbook. Teacher education, by implication, has to lead the way.

Each of the Big Six represents an authentic contest faced by historians. Seixas and Morton (2012) note, "each historical thinking concept reveals a tension, or difficulty, that may be irresolvable in any ultimate way" (p. 3). This conceptual framework can serve as a powerful tool in teacher education for the introduction of that same "controversy and uncertainty," which Engle, cited above, believed was the key to authentic teaching and learning experiences in Social Studies.

This framework serves as a means of developing historical literacy. With respect to teacher candidates, this means cultivating habits of mind and action. While each of the Big Six entails a way of examining the past, each also serves as a lens for framing contemporary social problems: a) Establishing significance of particular questions or contexts; b) Examining primary sources in addition to secondary source materials; c) Contemplating both the causes and consequences of phenomena or events; d) Exploring forces of continuity and change; e) Bearing in mind multiple perspectives; and $f$ ) Considering ethical questions. By incorporating each of them into the Ontario Social Studies curriculum, the Ministry of Education has made it clear that the Big Six have a broader and more potent purpose. Each began as a habit of authentic historical research, but has been adopted as a critical element of Social Studies education and, by implication, of civic life.

\section{Social Studies, Social Ethics}

The seminal purpose of Social Studies education can be conceived as a fundamentally ethical one. How ought we to live? What is our relationship to others? 
What is our role within the democratic state? Thus conceived, Social Studies is not something that teacher candidates must study, it is something that they ought to do. It is a means of developing engaged and historically literate citizens who practice the habits of mind that historical study helped to cultivate. For teacher candidates, Social Studies education can be transformed by the introduction of Take Action projects in the elementary school.

Such an approach in teacher education would resemble a project-based learning approach, which research has shown to foster community, particularly in diverse contexts (Lave \& Wenger 1991; Cornelius \& Herrenkohl, 2004; Beneke \& Ostrosky, 2009), and to have a positive effect upon knowledge retention (Thomas, 2000). Ohn and Wade (2009) demonstrate that project-based learning is most effective when concentrated upon service to the local community. Ferguson (2012) has demonstrated how her introduction of such projects during the practicum at the University of Prince Edward Island has helped teacher candidates emerge as leaders and innovators in their communities. In teacher education, Social Studies Methods classrooms-required of all teacher candidates in the province of Ontario prior to certification-offer fertile ground for practice and development of disciplinary thinking and application.

\section{Taking Action in Social Studies Classrooms}

What might Take Action projects in teacher education programs entail? There are seven steps that can frame authentic Social Studies proposed projects, which have been articulated at greater length by Craig Harding and Alan Sears in the Social Studies Handbook entitled, "Take Action - Make a Difference" (2008). Guided by student interests, local context, and news stories, teachers can ask students to: a) Identify a concern in the local community, rooted in the notion of social justice; b) Research this concern, examining various points of view and actions that they could take to ameliorate the matter; c) Find out who the stakeholders are, and who might support the concern; d) Create a plan, which involves deciding what actions can be taken and how to involve various stakeholders; e) Take action, implementing the plan; f) Evaluate the plan and actions, reflecting on the experience and the actions taken; and g) Share the results of the action plan with peers and with teachers in the Social Studies.

Each step concentrates teacher candidates upon central questions, and opens up instructional opportunities, which can be collectively, cooperatively, or individually approached. Harding and Sears' text is written for students in the elementary years, featuring colourful images and transparent instructions. Its clarity of articulation serves 
to make it useful, also, for teacher candidates who are deliberating the curricular potential and traditions of the Social Studies.

Table 1 serves as a précis of the suggested framework and questions that can be used to guide the students' activities. Table 2 identifies activities that can be pursued by teacher candidates during their practica with relation to each step, both within the primary and the junior classrooms. Each table elaborates on questions raised in Harding and Sears' work.

\section{Table 1}

\section{Suggested Framework and Questions}

\begin{tabular}{|l|l|}
\hline SEVEN STEPS & CENTRAL QUESTIONS \\
\hline 1. Identify your concern. & $\begin{array}{l}\text { What is my concern? } \\
\text { Why am I concerned? } \\
\text { What do I hope to achieve by becoming involved? }\end{array}$ \\
\hline 2. Research your concern. & $\begin{array}{l}\text { Where can I get information about this? } \\
\text { What are the different points of view? } \\
\text { What actions could I take? }\end{array}$ \\
\hline 3. Find out who supports you. & $\begin{array}{l}\text { Who else might be interested in taking action? } \\
\text { How can I get others involved? }\end{array}$ \\
\hline 4. Create a plan. & $\begin{array}{l}\text { Are we going to take any action? } \\
\text { If so, what action are we going to take? } \\
\text { Who do we need to talk to? }\end{array}$ \\
\hline 5. Take action. & $\begin{array}{l}\text { Are we doing what we planned to do? } \\
\text { Do we need to make any changes to our plan? }\end{array}$ \\
\hline 6. Evaluate the plan. & $\begin{array}{l}\text { What part of the plan worked well? } \\
\text { What part didn't work? } \\
\text { What did we learn from our experience? }\end{array}$ \\
\hline 7. Apply your learning. & $\begin{array}{l}\text { How can we apply our results? } \\
\text { How might we build on our action? }\end{array}$ \\
\hline
\end{tabular}


Table 2

\section{Activities for Teacher Candidates}

\begin{tabular}{|c|c|c|}
\hline SEVEN STEPS & $\begin{array}{l}\text { ACTIONS FOR THE PRIMARY } \\
\text { CLASSROOM }\end{array}$ & $\begin{array}{l}\text { ACTIONS FOR THE JUNIOR } \\
\text { CLASSROOM }\end{array}$ \\
\hline $\begin{array}{l}\text { 1. Identify your } \\
\text { concern. }\end{array}$ & $\begin{array}{l}\text { - Conduct a class survey. } \\
\text { - Go for a neighbourhood } \\
\text { walk to identify concerns. }\end{array}$ & $\begin{array}{l}\text { - Conduct a class and school } \\
\text { survey. } \\
\text { - Conduct an online poll. }\end{array}$ \\
\hline $\begin{array}{l}\text { 2. Research your } \\
\text { concern. }\end{array}$ & $\begin{array}{l}\text { - Bring in a guest speaker from } \\
\text { a community organization. } \\
\text { - Get input from school } \\
\text { administration and other } \\
\text { teachers about possible } \\
\text { courses of action and } \\
\text { perceptions of the issue. }\end{array}$ & $\begin{array}{l}\text { - Identify service } \\
\text { organizations-local, national, } \\
\text { and international-that take } \\
\text { action. Explore their websites. } \\
\text { - Examine newspapers for } \\
\text { coverage of the concern } \\
\text { identified. }\end{array}$ \\
\hline $\begin{array}{l}\text { 3. Find out who } \\
\text { supports you. }\end{array}$ & $\begin{array}{l}\text { - Telephone government } \\
\text { offices (with respect to local } \\
\text { concerns, the city council, or } \\
\text { the office of the mayor). } \\
\text { - Reach out to service } \\
\text { organizations involved in } \\
\text { similar projects. } \\
\text { - Compose a letter, an email, } \\
\text { and a list of questions for } \\
\text { interviews collaboratively. }\end{array}$ & $\begin{array}{l}\text { - Telephone and email } \\
\text { government offices (with } \\
\text { respect to local concerns, the } \\
\text { city council, or the office of } \\
\text { the mayor). } \\
\text { - Reach out to service } \\
\text { organizations involved in } \\
\text { similar projects. } \\
\text { - Begin by introducing } \\
\text { students to letter writing, } \\
\text { appropriate composition of } \\
\text { email messages, and qualities } \\
\text { of effective questions for } \\
\text { telephone conversations. }\end{array}$ \\
\hline 4. Create a plan. & $\begin{array}{l}\text { - Collaboratively brainstorm } \\
\text { ideas for taking action. } \\
\text { Create a collective mind } \\
\text { map. } \\
\text { - Narrow down the } \\
\text { possibilities to two or three } \\
\text { steps of action. } \\
\text { - List these steps and } \\
\text { set deadlines for } \\
\text { implementation that suit the } \\
\text { class schedule. } \\
\text { - Discuss with the class how } \\
\text { you will address the steps } \\
\text { that you have listed, and } \\
\text { begin to assign roles for each } \\
\text { member of the classroom. }\end{array}$ & $\begin{array}{l}\text { - Model how to brainstorm } \\
\text { ideas for taking action. } \\
\text { - Allow students opportunities } \\
\text { to create a mind map } \\
\text { independently. } \\
\text { - Model how ideas can } \\
\text { be clustered and how to } \\
\text { generate several concrete } \\
\text { steps to pursue in taking } \\
\text { action. } \\
\text { - Allow students opportunities } \\
\text { (independently or in small } \\
\text { groups) to generate steps for } \\
\text { taking action based on their } \\
\text { interest and sequence these. }\end{array}$ \\
\hline
\end{tabular}


Table 2

Activities for Teacher Candidates (cont.)

\begin{tabular}{|c|c|c|}
\hline SEVEN STEPS & $\begin{array}{l}\text { ACTIONS FOR THE PRIMARY } \\
\text { CLASSROOM }\end{array}$ & $\begin{array}{l}\text { ACTIONS FOR THE JUNIOR } \\
\text { CLASSROOM }\end{array}$ \\
\hline 5. Take action. & $\begin{array}{l}\text { - Create posters. } \\
\text { - Where appropriate, place a } \\
\text { notification for the action on } \\
\text { the school website. } \\
\text { - Call local media (newspapers } \\
\text { and radio) to raise awareness } \\
\text { of action. } \\
\text { - Follow the steps outlined in } \\
\text { the action plan. } \\
\text { - Develop a class checklist to } \\
\text { keep track of progress. } \\
\text { - On a daily or weekly basis, } \\
\text { address the progress } \\
\text { made with the class, and } \\
\text { allow students to note any } \\
\text { successes or problems. }\end{array}$ & $\begin{array}{l}\text { - Create posters and distribute } \\
\text { those throughout the school } \\
\text { and, where appropriate, the } \\
\text { community. Use social media } \\
\text { and the school website to } \\
\text { spread the word. } \\
\text { - Call local media (newspapers } \\
\text { and radio) to raise awareness } \\
\text { of action. } \\
\text { - Follow the steps outlined } \\
\text { in the action plan and track } \\
\text { these as a class. } \\
\text { - Individual students can keep } \\
\text { a journal of their actions and } \\
\text { reflections. } \\
\text { - Develop checklists for } \\
\text { individual and collective } \\
\text { action. }\end{array}$ \\
\hline $\begin{array}{l}\text { 6. Evaluate the } \\
\text { plan. }\end{array}$ & $\begin{array}{l}\text { - Discuss what the results of } \\
\text { taking action were. } \\
\text { - What worked? } \\
\text { - What did not work? } \\
\text { - What would you have } \\
\text { done differently? }\end{array}$ & $\begin{array}{l}\text { - Discuss what the results of } \\
\text { taking action were. Students } \\
\text { can write a response to the } \\
\text { teacher and to any supporting } \\
\text { agencies reflecting on the } \\
\text { plan. } \\
\text { - What worked? } \\
\text { - What did not work? } \\
\text { - What would you have } \\
\text { done differently? }\end{array}$ \\
\hline $\begin{array}{l}\text { 7. Apply your } \\
\text { learning. }\end{array}$ & $\begin{array}{l}\text { - Invite the school to your } \\
\text { classroom or the auditorium } \\
\text { and share the learning. } \\
\text { - Create a poster display to } \\
\text { highlight the action taken } \\
\text { and the lessons learned. }\end{array}$ & $\begin{array}{l}\text { - Develop a class symposium, } \\
\text { where each group or } \\
\text { individual has time to share } \\
\text { learning. Invite parents, the } \\
\text { school, and the community. } \\
\text { - A poster session is an } \\
\text { alternative to a symposium. } \\
\text { - Develop a website and } \\
\text { publish the summaries of } \\
\text { each take action project's } \\
\text { work. }\end{array}$ \\
\hline
\end{tabular}


The charts above serve as suggestions for teacher candidates at the Primary and Junior levels. They suggest that primary classrooms begin with a whole-class project and collaborative writing or reflection tasks. In the junior grades, Take Action projects can be individual, but also organized collectively or in small groups.

\section{Taking Action Beyond Teacher Education}

Recently, 80 teacher candidates in Trinidad and Tobago undertook the responsibility of integrating Take Action projects into their teaching at the elementary level (Take Action, 2013). As is the case in Ontario, these teachers spend nearly the entire school day with their students, and could seek opportunities to integrate the Social Studies projects with other subjects, primarily literacy. The classrooms were all within the capital region, near Port of Spain.

The teachers had between eight and 24 years of experience in the classroom. The projects undertaken engaged the whole classroom, rather than asking each student to work individually or in small groups to address a social concern. The projects engaged local concerns - such as noise pollution outside of the school-and international ones such as the activism of groups including Habitat for Humanity. Each teacher candidate engaged his or her classroom with the project for a period ranging from three to five months, following the framework outlined by Harding and Sears.

An online publication documents reports and descriptions of Take Action projects completed in 2012 and 2013 by teacher candidates enrolled in three distinct Bachelor of Education programs (Take Action, 2013). One of these programs is located in Trinidad and Tobago; the others represent teacher education institutions in two Canadian provinces. Table 3 is the summary of one project, which serves as an indicative example of a Take Action project tailored to the elementary Social Studies classroom. This project was developed by a teacher candidate and applied within the context of her practice teaching. 


\section{Table 3}

\section{Suggested Framework and Questions}

\begin{tabular}{|l|l|}
\hline SEVEN STEPS & CENTRAL QUESTIONS \\
\hline 1. Identify your concern. & $\begin{array}{l}\text { The school garden has fallen into disrepair. A new } \\
\text { school garden is needed, but space is limited. }\end{array}$ \\
\hline 2. Research your concern. & $\begin{array}{l}\text { Information gathered pertained to the best } \\
\text { methods and techniques for gardening using } \\
\text { grow boxes. }\end{array}$ \\
\hline 3. Find out who supports you. & $\begin{array}{l}\text { The school staff pledged to support its } \\
\text { maintenance. The community donated tools and } \\
\text { fertilizer, while volunteering labour. }\end{array}$ \\
\hline 4. Create a plan. & $\begin{array}{l}\text { Three steps were outlined: a) teach students } \\
\text { about planting and maintaining garden in grow } \\
\text { boxes; b) planting the garden; and c) maintaining } \\
\text { the garden. }\end{array}$ \\
\hline 5. Take action. & $\begin{array}{l}\text { Seeds were planted and watered daily. The } \\
\text { teacher continued to model how to maintain } \\
\text { these plant boxes. Class reflected on values } \\
\text { embedded in practice, which included shared } \\
\text { responsibility and cooperation. }\end{array}$ \\
\hline 6. Evaluate the plan. & $\begin{array}{l}\text { The teacher monitored the garden's progress, } \\
\text { while also reflecting upon the students' ability } \\
\text { to work cooperatively to achieve common aims. }\end{array}$ \\
\hline
\end{tabular}

The above is one example of how it is possible to engage teacher candidates with the planning and implementation of projects that apply their learning in teacher education directly to the needs of a classroom and, what is more, to the disciplinary foundations of a curricular subject. The actual subject of a Take Action project should be derived with the context and the students' interests in mind, which is a challenge, that teacher candidates grapple with by necessity during their teaching practice. The above framework offers a means of aligning Social Studies education to its historical purposes, while also serving to foster an ethic of active citizenship within the context of teacher education. 


\section{Conclusions}

Teacher candidates are in a unique position to learn about the curriculum subjects that are the foundation of public schooling even as they determine how they might foster meaningful teaching and learning environments within the enabling constraints of these subjects. The best way to learn about the Social Studies is to participate authentically and meaningfully with actions that exemplify engaged citizenship and historical thinking. John Dewey (1936) explained this most succinctly:

Democracy as a personal, an individual, way of life involves nothing fundamentally new. But when applied it puts a new practical meaning in new ideas. ... Democracy as compared with other ways of life is the sole way of living which believes wholeheartedly in the process of experience as end and as means. (pp. 224-230)

The Social Studies classroom offers a unique opportunity for teacher candidates to analyze the world around them and to engage with this world in light of an ongoing study of its complexities. This involves grappling with authentic social questions and problems that challenge the way that teacher candidates think about the past and the present. Social Studies education has the potential to serve as the principal vehicle for engaging teacher candidates meaningfully within the teaching and learning communities they occupy while drawing to the forefront the moral imperative of pursuing a socially responsible and just vision for educational action.

History, Geography, Language, and Mathematics can be integrated within a projectbased learning approach at the elementary level, where the teacher has the opportunity to teach students for most of the day. Each discipline, bound by the Social Studies, serves to foster understanding of the complex relationship binding school subjects and life lived outside of the school grounds. This is fundamental when recognizing that the Social Studies can devolve into the benign study of past places and events even as its foundation called for an interdisciplinary approach to teaching that necessitates a dynamic engagement with lived experience. Take Action projects, woven into teacher education, may serve as means of drawing the Social Studies classroom from the medieval world to the contemporary one, in both a literal and a figurative sense. 


\section{References}

Beneke, S., \& Ostrosky, M. M. (2009). Teachers' views of the efficacy of incorporating the project approach into classroom practice with diverse learners. Early Childhood Research and Practice, 11(1).

Bouvier, F., M. Allard, P. Aubin, \& M.-C. Larouche (Eds.). (2012). L'histoire nationale à l'école québécoise, regards sur deux siècles d'enseignement. Quebec, QC: Septentrion.

Boyle-Baise, M., \& Zevin, J. (2013). Young citizens of the world: Teaching elementary social studies through civic engagement. New York: Routledge.

Christou, T. (2012). Progressive education: Revisioning and reframing Ontario's public schools, 1919-1942. Toronto, ON: University of Toronto Press.

Christou, T. (2013). The complexity of intellectual currents: Duncan McArthur and Ontario's progressivist curriculum reforms. Paedagogica Historica, 49(5), 677-697.

Cornelius, L. L., \& Herrenkohl, L. R. (2004). Power in the classroom: How the classroom environment shapes students' relationships with each other and with concepts. Cognition and Instruction, 22(4), 467-498.

Dewey, J. (1907). The school and the society. New York: Macmillan.

Dewey, J. (1936). Creative democracy: The task before us. In Boydston J. (Ed.). (1976). John Dewey: The later works, 1925-1953, Volume 14 (pp. 224-230). Carbondale, IL: Southern Illinois University Press.

Engle, S. H. (1986). Late night thoughts about the new social studies, Social Education, 50(1), 20-22.

Éthier, M.-A., \& Lefrançois, D. (2011). Learning and teaching history in Quebec: Assessment, context, outlook. In P. Clark (Ed.). New possibilities for the past: Shaping history education in Canada (pp. 325-343). Vancouver, BC: UBC Press.

Ferguson, J. L (2012). The university course as the site for positioning pre-service teachers as agents of change. Paper presented at Sixth Working Conference on Research in Teacher
Education in Canada. November 1-3, 2012, McGill University, Montreal, QC

Harding, C. J., \& Sears, A. (2008). Take action: Make a difference. Toronto, ON: Pearson.

Lave, E., \& Wenger, E. (1991). Situated learning: Legitimate peripheral participation. Cambridge, UK: Cambridge University Press.

Létourneau, J. (2011). The debate on history education in Quebec. In P. Clark (Ed.), New possibilities for the past: Shaping history education in Canada (pp. 325-343). Vancouver, BC: UBC Press.

Lortie, D. C. (1975). Schoolteacher: A sociological study. Chicago: University of Chicago Press.

Ohn, J. D., \& Wade, R. (2009). Community service-learning as a group inquiry project: Elementary and middle school CiviConnections teachers' practices of integrating historical inquiry in community service-learning. Social Studies, 100(5), 200-211.

Ontario Ministry of Education. (2013). The Ontario curriculum: Social Studies, Grades 1-6. Toronto, ON: The Queen's Printer for Ontario.

Osborne, K. (2012). Foreword. In Seixas, P., \& Morton, T. (2012), The big six: Historical thinking concepts. Toronto, ON: Nelson.

Quebec Ministry of Education. (2001). Québec education program: Approved version. Quebec City, QC: Gouvernement de Québec.

Sarason, S. B. (1996). Revisiting "the culture of the school and the problem of change." New York: Teachers College Press.

Seixas, P., \& Morton, T. (2012). The big six: Historical thinking concepts. Toronto: Nelson.

Take Action: Citizenship and Social Studies Projects. (2013). Retrieved from: http:// theodorechristou.ca/tmc/Take_Action_Citizenship_and_Social_Studies_Projects. html

Thomas, J. W. (2000). A review of projectbased learning. San Rafael, CA: Autodesk Foundation. 
von Heyking, A. (2006). Creating citizens: History and identity in Alberta's schools, 1905 to 1980. Calgary: University of Calgary Press.
Wade, R. (2002). Beyond expanding horizons: New curriculum directions for elementary social studies, The Elementary School Journal, 103(2), 115-130.

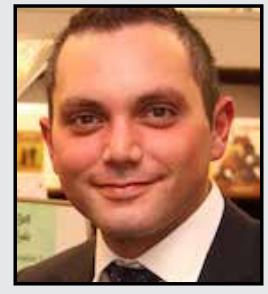

Theodore Michael Christou is an Assistant Professor at Queen's University. He began his academic career at the University of New Brunswick in 2009. Theodore's teaching and research pertain to the history and philosophy of education. $\mathrm{He}$ is the author of The Problem of Progressive Education (University of Toronto Press, 2012), winner of the Canadian History of Education Association's Founders Prize, and of an overbearing eye (Hidden Brook Press, 2013), a book of verse and short fiction. Theodore is also the co-editor (with Shawn Michael Bullock) of Foundations in Teacher Education: A Canadian Perspective (Canadian Association for Teacher Education, 2013).

LINK TO:

http://historicalthinking.ca

http://educ.queensu.ca/faculty/profiles/christou 